\title{
Analysis of Incremental Load Damaging Effects of Overloaded Trucks on Federal Highway Pavement Structures in Nigeria
}

\author{
Olufemi Jacob Oyekanmi' ${ }^{1}$ Ejem Agwu Ejem² \\ ${ }^{1}$ Federal Ministry of Works and Housing, Abuja, Nigeria \\ ${ }^{2}$ Department of Transport Management Technology, Federal University of Technology, Owerri, Nigeria \\ Email: femiolion@yahoo.com, ejemflagospel@yahoo.com
}

How to cite this paper: Oyekanmi, O.J. and Ejem, E.A. (2020) Analysis of Incremental Load Damaging Effects of Overloaded Trucks on Federal Highway Pavement Structures in Nigeria. Journal of Transportation Technologies, 10, 306-324.

https://doi.org/10.4236/jtts.2020.104020

Received: August 11, 2020

Accepted: September 25, 2020

Published: September 28, 2020

Copyright (c) 2020 by author(s) and Scientific Research Publishing Inc. This work is licensed under the Creative Commons Attribution International License (CC BY 4.0).

http://creativecommons.org/licenses/by/4.0/

\begin{abstract}
The study is to assess the present serviceability rating of Nigerian highways and the load damage effects of overloaded trucks. The researchers used the American Association of State Highway and Transportation Officials (AASHTO) methods. In this study, the highway section of Lokoja-Abuja, Ilorin-Jebba and Abakiliki-Ogoja via Mbok roads were selected, and data were collected through an axle-load survey, automatic traffic count and from secondary sources. The rate of gross vehicle weight violation was found, ranging from $20 \%$ to $94 \%$ of the axle load distribution across the studied network. Comparing the overloaded vehicle damage factor (V.D.F.) and standard V.D.F., the range was from 1.2 to 41.34 times across the road networks studied, and this explained why the pavement structures of Nigerian roads tend to deteriorate during its service life rapidly. Present serviceability rating was estimated at 3.45, 4.41 and 3.35 for Lokoja-Abuja, Ilorin-Jebba and Abakiliki-Ogoja roads respectively, showing depletion from their initial conditions. The damaging effects of the HGV are more severe at Lokoja-Abuja Road (with $g=0.30$ ), followed by Ilorin-Jebba Road (with $g=0.35$ ) and in Abakiliki-Ogoja Road (with $g=0.43$ ). The heaviest overload of $94 \%$ of the 6 -axle vehicles plying at the Lokoja-Abuja road could explain this intense damaging effect on the road pavement.
\end{abstract}

\section{Keywords}

Pavement, Damage, Overloading, Pavement Serviceability Rating, Nigerian Highway

\section{Introduction}

Overloading of trucks is now a common scene on Nigeria roads and it is not 
surprising to see vehicles carrying as much as twice the legally permissible axle loads on the roads. The road network in Nigeria comprises of federal, states and local government roads. The development of modern roads along the major arterials is funded by the Federal Government. Several studies have been completed and some are still in progress for the purpose of understanding the effect of overloading on the road pavement. It is opined globally that heavy and overweight trucks are a major cause of highway deterioration and that their damaging effects make it clear that trucks are the principle cause of traffic related deterioration of the highways. In an age of deteriorating highway infrastructure and declining budgets for road upgrades and repairs, the sensible thing to do in order to lengthen the lifespan of our roadways would be to shift even more cargo transport from truck to rail and enforcement of weight and Axle load controls on the existing road infrastructure.

It is essential for those responsible for the maintenance of highway infrastructures to monitor and prevent overloading. The excess weight carried by overloaded trucks accelerates the deterioration of the roadway, leading to rutting, fatigue cracking, and in some instances structural failure [1] [2]. [3] highlighted that illegally loaded trucks were estimated to cost United States from $\$ 160$ to $\$ 670$ million annually on the highway. Reference [4] did a study to quantify state highway damage based on the impacts of overweight vehicles. Every year, millions of dollars of damage associated with economic life, pavement design, and maintenance of highways and structures are attributed to overloaded vehicles. It was observed that for every dollar invested in enforcement, there would be $\$ 4.50$ in pavement damage cost avoided. It is possible to come up with strategies that would increase the proportion of non-compliant vehicles [5]. Overloading increases road pavement damage and its decreases in service life has also been confirmed by [6] and an analysis of the cost of road pavement distress due to overloading freight transportation was also presented.

The road pavement is designed based on the cumulative axle load that the pavement is expected to carry during its design life. This is because every axle load impact induces some permanent strain on the pavement which culminates to cause failure. Overloading exerts more load than the pavement is designed to carry which leads to rapid and premature failure of road pavement. Axle load survey carried out in 2008 in Nigeria revealed over $48 \%$ of trucks are overloaded and exceed the legal maximum axle load of 11.5 tons [7]. Hence, the above presents overview of the present status of the Nigeria road network, policy and practices which includes design standards and the permissible axle load standards, control, enforcement of loading regulations and the consequence of a breach of the loading regulation of the road network. The big question is: was there any study to determine the incremental damaging effect resulting from an extra kilogramme of overloading? There is therefore a need for research in the estimation of the damaging effect on the road network incidental to overloading using data obtained from some key roads in Nigeria. This will enable us determine the commensurate penalties and appropriate charges for axle load viola- 
tion on our roads.

\section{Review of Empirical Literature}

Reference [8] quantified incremental pavement damage caused by overweight trucks in Saskatchewan, Canada. They confirmed that accelerated damage from overloading has decreased the serviceability ratings of many of the roads and also increased maintenance and rehabilitation burden. The effect of overload on the performance of articulated vehicles has been studied by [9]. Three measures were used to assess and characterize vehicle performance, namely, dynamic stability, braking and handling gradient. Vehicle performance characteristics were obtained with the use of a simulation software. References [9] [10] [11] observed that high grade vehicle gross vehicle weight has a direct effect on speed, whether the vehicle travel in a vehicle following situation or free-flow level of service. An overloaded vehicle has more tendency to be involved in an accident and has fatal consequences than a normally loaded vehicle [12]. Overtaking also takes longer, and thus incurs additional risks for the other road users [12].

In [13], the study continued to classify vehicles according to broad weight categories (primary vehicles weighing 10,000 pounds or less and heavy vehicles weighing more than 10,000 pounds). It identified the total value of diverted highway user funds (e.g., federal highway user funds used to support mass transit programs and ad-valorem taxes passed through to counties) but did not allocate them. The study explored methods collectively fall under the umbrella of the cost-occasioned approach, which shows cost responsibility based on the costs occasioned by different highway user classes. The cost-occasioned approach attempts to allocate cost responsibility based on the costs imposed on the highway network by each class of highway users, as opposed to allocating costs simply based on relative use. The substantial truck share varies due to several factors, including the scope and type of expenditures, the definition of the heavy truck class (some weight threshold or vehicle configuration generally defines the heavy truck class), the methods used in the study, and the types of expenditures examined. The measure used to allocate costs to highway user classes, is generally tied to either travel (e.g., V.M.T.), the space vehicles take up on roads (e.g., passenger car equivalents [PCEs]), vehicle loads (e.g., equivalent single axle loads [ESALs]) or a combination of these measures. The results were conducted concerning the equity ratios for the heavy truck class. As noted previously, the definition of the heavy truck class is differentiated among states but generally includes all vehicles weighing over a certain weight threshold (e.g., 10,000 pounds) or is identified based on vehicle characteristics (e.g., all vehicles with more than two axles). The heavy vehicle class typically includes buses, single-unit trucks, and combination trucks. The equity ratio is measured as the revenues attributed to the highway user class divided by its cost responsibility. An equity ratio of less than 1.0 would indicate that payments from the highway user class have fallen short of its cost responsibility. 
In contrast, an equity ratio above 1.0 would indicate that tax payments exceed cost responsibility. The various studies found that payments from the heavy truck class fell short of cost responsibility. In three states (Delaware, Montana, and Oregon), substantial truck payments were equal to or greater than their cost responsibilities. The explanation of the results is tied to the differences in the state tax. One of the three states (Oregon) in the over 1.0 equity ratio category had weight-distance taxes at the time of the study, and another (Delaware) collected a high proportion of its substantial truck revenues from out-of-state based trailers [13]. There is, therefore, an ongoing need in Nigeria to inform transporters unusually heavy-duty transporters of the severe overloading consequences. It is time to give them some guidance, where necessary, on how to load multiple rear-axle trucks in order to make full use of permitted axle loading while still avoiding the illegal overloading of any of the axles involved. The cooperation of transporters in complying with vehicle axle load limits is vital if the condition of our highway pavement is to be kept consistently good. Only when such cooperation is obtained will road authorities be able to maximize the value for money invested on the roads.

Examining the relationship between the numbers of axles of each truck category and the changes in gross vehicle weight, the coefficient was 0.855 which was significant at 0.01 level, indicating a great effect of the number of axle to overloading on the Nigerian road. The analysis showed that the axle load from weigh-in-motion data is hugely greater than ECOWAS standard weight in Lokoja-Abuja road, which may lead to accelerated deterioration, reducing the service life of the pavement structures. Overloading is most critical to the life span of a highway pavement. There is no single enforcement of axle load regulations in Nigeria today. The worst scenario is that the roads deteriorate as soon as the road is commissioned. The only agency of Government enforcing overloading regulations in Nigeria today is the Federal Roads Safety Corp whose interest is seen only in passenger movement [14]. They cannot enforce excessive Axle load regulations. Weighbridges are presently not in operation in Nigeria, but the Federal Ministry of Works is in the process of returning weighbridges along with the Federal Road network [14]. An analysis indicates that the vehicle damage factor from axle-load survey is hugely higher than vehicle damage factor of the conventional national standard. It may lead to accelerated deterioration, reducing the service life of the pavement structures [15].

\section{Methodology}

Traffic data was collected within four months beginning from January 2019 using weigh-in-motion facilities operated by Exosphere Nig. Ltd. The gross vehicle weight (G.V.W.) of all vehicle categories, was obtained from a weigh-in-motion system installed on survey points. A thorough analysis of the vehicle data was obtained to determine the vehicle overloading characteristics at the study location. The G.V.W. permissible is categorized based on vehicle class. For this pa- 
per, the focus will be given to the 1-axle, 2-axle, 3-axle, 4-axle trucks, 5-axle and 6-axle. The number of overloaded trucks will be shown at each study location. This study made conservative assumptions to model the incremental load damage effects of overweight trucks to selected federal highway pavement structures. Modelling of traffic loadings on the pavement is vital in the pavement deterioration models. Traffic loadings on the pavement are directly related to weight transfer to a road surface by vehicle axles. Axle load equivalency factors are used to define the effects of different truck configurations. In addition to modelling the effects of axle passes, it is necessary to measure the serviceability of pavement segments for the estimation of pavement damage. The applications of truck and pavement characteristics are critical parts in this pavement damage cost study.

The detail of the survey location presented a piece of information about the type of truck, class and their standard V.D.F. The truck information was collected by interviewing the driver and his crew. There are six (6) types of trucks that were considered in the analysis of this study. This V.D.F. standard was compared with the V.D.F. value generated from W.I.M. data survey. The percentages of the overloaded truck were estimated by identifying truck axle load that is greater than the maximum legal limit. A figure was presented to show that the percentage of the overloaded trucks varies for each type of truck and survey location.

Vehicle Damage Factor was used as a representation of the trucks that was encountered on the pavement structure. It was also defined as the equivalent number of standard axles per truck. The V.D.F. was estimated by using the empirical approach through the 4 th power formulas derived by Liddle [16]

$$
\mathrm{DF}=k(Q i / Q s)^{4}
$$

where:

DF: Damage Factor,

Qi: Actual Load,

Qs: standard single axle load $80 \mathrm{kN}, k$ : 1 for single, 0.086 for tandem and 0.053 for tridem axle load.

The vehicle damage factor was estimated from survey data. Since the survey was conducted in different months, V.D.F. value was estimated by analyzing for each month and location of the survey. Further analysis was done by using the V.D.F. value of a common truck type to check the tendency of the overloaded truck. A conventional truck type chosen is this kind of truck that constitutes the majority in the daily traffic data. A table showed a comparison between overloaded V.D.F. and standard V.D.F. A percentage was used to describe the total number of trucks that have a V.D.F. value more than V.D.F. standards.

\subsection{Present Serviceability Rating}

In addition to modelling the effects of axle passes, it is necessary to measure the serviceability of pavement segments for the estimation of pavement damage. The application of pavement characteristics in pavement deterioration models played 
another critical role in this pavement damage cost study. Based on individual observations, the AASHTO Road Test developed the present serviceability rating (P.S.R. or $p$ ) as the judgment of an observer as to the current ability of pavement to serve the traffic it is meant to serve [16]. Table 1 is the basis of interpretation of the present serviceability rating of the road pavement selected for study in this paper.

\subsection{Determination of the Index of Damage or Deterioration}

The deterioration of pavements was analyzed with a damage function that related to the decline of pavement serviceability to traffic or axle passes. According to [16], the general form of a damage function is illustrated as follows:

$$
G=(N / \tau)^{\beta}
$$

where:

$g=$ an index of damage or deterioration;

$N=$ the number of passes of an axle group of specified weight and configuration (e.g., a single 18-kip axle);

Table 1. Present serviceability rating.

\begin{tabular}{|c|c|c|}
\hline $\begin{array}{l}\text { Present Serviceability } \\
\text { Rating (P.S.R.) }\end{array}$ & Rating & Description \\
\hline $4.0-5.0$ & Excellent & $\begin{array}{l}\text { Only new (or nearly new) superior pavements are likely to be } \\
\text { smooth enough and distress free (sufficiently free of cracks and } \\
\text { patches) to qualify for this category. Most pavements } \\
\text { constructed or resurfaced during the data year would generally } \\
\text { be rated in this category. }\end{array}$ \\
\hline $3.0-4.0$ & Good & $\begin{array}{l}\text { Pavements in this category, although not quite as smooth as } \\
\text { those described above, give a first-class ride and exhibit few, if } \\
\text { any, visible signs of surface deterioration. Flexible pavements } \\
\text { may be beginning to show evidence of rutting and fine random } \\
\text { cracks. Rigid pavements may be beginning to show evidence of } \\
\text { slight surface deterioration, such as minor cracking and spalls. }\end{array}$ \\
\hline $2.0-3.0$ & Fair & $\begin{array}{l}\text { The riding qualities of pavements in this category are noticeably } \\
\text { inferior to those of the new pavements and may be barely } \\
\text { tolerable for high-speed traffic. Surface defects of flexible } \\
\text { pavements may include rutting, map cracking, and extensive } \\
\text { patching. Rigid pavements may have a few joint fractures, } \\
\text { faulting and cracking, and some pumping. }\end{array}$ \\
\hline $1.0-2.0$ & Poor & $\begin{array}{l}\text { Pavements have deteriorated to such an extent that they affect } \\
\text { the speed of free-flow traffic. Flexible pavement may have } \\
\text { significant potholes and deep cracks. Distress includes ravelling, } \\
\text { cracking, and rutting and occurs over } 50 \text { per cent or more of the } \\
\text { surface. Rigid pavement distress includes joint spalling, faulting, } \\
\text { patching, cracking, and scaling and may include pumping and } \\
\text { faulting. }\end{array}$ \\
\hline $0-1$ & Very poor & $\begin{array}{l}\text { Pavements are in extremely deteriorated conditions. The facility } \\
\text { is passable only at reduced speed and considerable ride } \\
\text { discomfort. Large potholes and deep cracks exist. Distress occurs } \\
\text { over } 75 \text { per cent or more of the surface }\end{array}$ \\
\hline
\end{tabular}

Source: [16]. 
$\tau=$ the number of axle passes at which the pavement reaches failure (e.g., the theoretical life of the pavement);

$\beta=$ deterioration rate for a given axle.

\subsection{Determination of Deterioration Due to Environmental Losses}

A pavement will deteriorate over time due to environmental factors in the absence of truck traffic. Thermal cracking, differential heaving due to swelling subgrade or frost penetration, the disintegration of surface materials due to freeze-thaw cycles, and other climatic/ageing effects on materials are primarily a function of the environment and will result in a loss of pavement serviceability. This function suggests that pavement condition declines rapidly when initially exposed to the environmental elements, but then deteriorates at a decreasing rate over time.

From Equation (2), assuming this theoretical relationship holds, the decay rate due to environmental conditions can be found using the following equation:

$$
\delta=-\ln \left(P_{t} / P_{i}\right) / L
$$

where:

$\delta=$ Decay rate due to environmental losses;

$P_{t}=$ Terminal PSR;

$P_{i}=$ Initial PSR;

$L=$ Maximum feasible life of pavement section.

From the decay rate, the P.S.R. due to the environmental impact can be computed as:

$$
P_{E}=P_{i} * e^{(-t \delta)}
$$

where:

$P_{E}=$ PSR due to the environment impact;

$t=$ Typical pavement performance period.

From the construction or replacement and the pavement failure, the value of $g$ will range between 0.0 and 1.0. When $N$ equals zero for a newly constructed or rehabilitated section, g equals zero. However, when $\mathrm{N}$ equals the life of a highway section $(\tau)$, g equals 1.0. One way to measure accumulated pavement damage is through a serviceability rating. If the ratio of decline in pavement serviceability relative to the maximum tolerable decline in serviceability is used to represent the damage index, then Equation (1) can be rewritten as follows:

$$
\left(P_{i}-P\right) /\left(P_{i}-P_{\tau}\right)=(N / \tau)^{\beta}
$$

where:

$$
\begin{aligned}
& P_{i}=\text { initial pavement serviceability rating; } \\
& P_{\tau}=\text { terminal pavement serviceability rating; } \\
& P=\text { current pavement serviceability rating. }
\end{aligned}
$$

\section{Results and Discussion}

In this study, the vehicle damage factor was estimated from weigh-in-motion 
(W.I.M.) survey (from Equation (1)). Since the W.I.M. survey was conducted on different days of the week, the vehicle damaging factor (V.D.F.) value calculated by analyzing for a day. The result shows that the V.D.F. value fluctuates along the axle configuration for the three roads studied. This can be explained by different categories of goods carried. In Lokoja-Abuja road, the high-grade vehicles were observed to carry more of cement and other building materials like steel reinforcement. The Ilorin-Jebba road was seen to carry more of petroleum products and general goods. However, Abakiliki-Ogoja road was observed to carry more agricultural products, mainly cocoa and a mix of petroleum products and cement. V.D.F. result (overloaded V.D.F.) was compared with the standard V.D.F. for each truck, as stated in Tables 2-4. From the analysis, the V.D.F. result was higher than standards vehicle damage factor except for single axle vehicles which are rarely overloaded. The range comparison between overloaded V.D.F. and standard V.D.F. is about 1.2 to 3.3 times. This is the reason why the pavement structures in Nigerian roads tend to rapidly deteriorates during its service life. The case is not different for Abakiliki-Ogoja road and Ilorin-Jebba road. Abakiliki-Ogoja road has the ratio of overloaded V.D.F. and standard V.D.F. at 41.34 times for two-axle vehicles. In Ilorin-Jebba road the ratio of overloaded V.D.F. and standard V.D.F. ranges from 1.50 times to 7.17 times, except for six-axle vehicles that recorded a ratio of 0 meaning there was not overloading at all in that class of vehicles.

The gross vehicle weight (G.V.W.) permit is categorized based on the vehicle class, and the summary was shown in Tables 2-4. For this study, the focus was given to 2-axle, 3-axle, 4-axle trucks, 5-axle and 6-axle categories of vehicles. A total of 43,514 commercial vehicle data obtained during a week in Lokoja-Abuja road, 12,927 in Abakaliki towards Mbok (27 ${ }^{\text {th }}$ January 2019 to $2^{\text {nd }}$ February 2019), 296,571 in Ilorin towards Jebba (Westbound) ( $15^{\text {th }}$ May 2019 to $21^{\text {st }}$ May 2019) from a weigh-in-motion (W.I.M.) system was analyzed. Tables 5-7 show the summary of automatic traffic count indicating the category of vehicle counted within each day of the week for study locations. The HGV's have $30.49 \%$ of the traffic components at Lokoja-Abuja road, $15.25 \%$ at Abakaliki towards Mbok

Table 2. Calculated V.D.F. for various classes of trucks along Lokoja-Abuja route.

\begin{tabular}{ccccccc}
\hline $\begin{array}{c}\text { Class of } \\
\text { Vehicle }\end{array}$ & $\begin{array}{c}\text { ECOWAS } \\
\text { Standard } \\
\text { Limit }\end{array}$ & $\begin{array}{c}\text { Total } \\
\text { Gross Weight }\end{array}$ & $\begin{array}{c}\text { No. within } \\
\text { Allowable } \\
\text { Gross Weigh }\end{array}$ & $\begin{array}{c}\text { V.D.F. } \\
\text { (overloaded) }\end{array}$ & $\begin{array}{c}\text { Vehicle } \\
\text { Damaging } \\
\text { Factor } \\
\text { (Standard) }\end{array}$ & $\begin{array}{c}\text { The ratio of } \\
\text { Overloaded } \\
\text { V.D.F. and } \\
\text { Stand V.D.F. }\end{array}$ \\
\hline 2-axle & 160,000 & 158,490 & 8 & 1.926 & 3.898 & 0.49 \\
3-axle & 156,000 & 172,300 & 3 & 4.464 & 3.679 & 1.21 \\
4-axle & $2,812,000$ & $3,444,860$ & 10 & 9.009 & 5.934 & 1.52 \\
5-axle & 720,000 & 815,040 & 4 & 8.210 & 6.222 & 1.32 \\
6-axle & $3,519,000$ & $4,728,340$ & 4 & 19.557 & 6.003 & 3.26 \\
\hline
\end{tabular}

Source: Authors' Computation, 2020. 
Table 3. Calculated V.D.F. for various classes of trucks along Abakiliki-Ogoja road.

\begin{tabular}{ccccccc}
\hline $\begin{array}{c}\text { Class of } \\
\text { Vehicle }\end{array}$ & $\begin{array}{c}\text { ECOWAS } \\
\text { Standard } \\
\text { Limit }\end{array}$ & $\begin{array}{c}\text { Total } \\
\text { Gross Weight }\end{array}$ & $\begin{array}{c}\text { No. within } \\
\text { Allowable } \\
\text { Gross Weigh }\end{array}$ & $\begin{array}{c}\text { Vehicle } \\
\text { (overloaded) }\end{array}$ & $\begin{array}{c}\text { The ratio of } \\
\text { Damaging } \\
\text { Factor } \\
\text { (Standard) }\end{array}$ & $\begin{array}{c}\text { Overloaded } \\
\text { V.D.F. and } \\
\text { Standard V.D.F. }\end{array}$ \\
\hline 2-axle & 160,000 & 479,370 & 28 & 161.15 & 3.898 & 41.34 \\
3-axle & 156,000 & 222,070 & 6 & 12.32 & 3.679 & 3.35 \\
4-axle & $2,812,000$ & 994,690 & 20 & 0.06 & 5.934 & 0.01 \\
5-axle & 720,000 & 310,150 & 6 & 0.17 & 6.222 & 0.03 \\
6-axle & $3,519,000$ & 254,830 & 8 & 0.00 & 6.003 & 0.00 \\
\hline
\end{tabular}

Source: Authors' Computation, 2020.

Table 4. Calculated V.D.F. for various classes of trucks along Ilorin-Jebba road.

\begin{tabular}{ccccccc}
\hline $\begin{array}{c}\text { Class of } \\
\text { Vehicle }\end{array}$ & $\begin{array}{c}\text { ECOWAS } \\
\text { Standard } \\
\text { Limit }\end{array}$ & $\begin{array}{c}\text { Total } \\
\text { Gross Weight }\end{array}$ & $\begin{array}{c}\text { No. within } \\
\text { Allowable } \\
\text { Gross Weigh }\end{array}$ & $\begin{array}{c}\text { V.D.F. } \\
\text { (overloaded) }\end{array}$ & $\begin{array}{c}\text { Vehicle } \\
\text { Damaging } \\
\text { Factor } \\
\text { (Standard) }\end{array}$ & $\begin{array}{c}\text { The ratio of } \\
\text { Overloaded } \\
\text { V.D.F. and } \\
\text { Standard V.D.F. }\end{array}$ \\
\hline 2-axle & 160,000 & 309,370 & 3 & 27.96 & 3.898 & 7.17 \\
3-axle & 156,000 & 267,040 & 1 & 25.76 & 3.679 & 7.00 \\
4-axle & $2,812,000$ & $3,433,190$ & 20 & 8.89 & 5.934 & 1.50 \\
5-axle & 720,000 & $1,071,470$ & 8 & 24.52 & 6.222 & 3.94 \\
6-axle & $3,519,000$ & 878,140 & 4 & 0.02 & 6.003 & 0.00 \\
\hline
\end{tabular}

Source: Authors' Computation, 2020.

Table 5. Summary of automatic traffic count showing axle load distribution for Lokoja-Abuja.

\begin{tabular}{cccccccc}
\hline & $2 \mathrm{aR}$ & $3 \mathrm{a} \mathbf{R}$ & $4 \mathrm{aR}$ & $3 \mathrm{aA}$ & $\mathbf{4 a A}$ & $5 \mathrm{aA}$ & $6 \mathrm{aA}$ \\
\hline $2 / 4 / 19$ & 705 & 148 & 134 & 3 & 303 & 165 & 357 \\
$3 / 4 / 19$ & 634 & 113 & 133 & 0 & 392 & 186 & 419 \\
$4 / 4 / 19$ & 751 & 122 & 173 & 3 & 390 & 186 & 505 \\
$5 / 4 / 19$ & 746 & 124 & 161 & 3 & 382 & 216 & 449 \\
$6 / 4 / 19$ & 723 & 112 & 173 & 3 & 396 & 156 & 365 \\
$7 / 4 / 19$ & 692 & 112 & 161 & 2 & 325 & 193 & 382 \\
$8 / 4 / 19$ & 502 & 93 & 149 & 0 & 330 & 166 & 328 \\
Total k & 4753 & 824 & 1084 & 14 & 2518 & 1268 & 2805 \\
\% overloaded & $20 \%$ & $50 \%$ & $86 \%$ & $50 \%$ & $86 \%$ & $73 \%$ & $94 \%$ \\
\hline
\end{tabular}

Note: a-axle, R-Rigid Vehicles, A-Articulated Vehicles. Source: Authors' Computation, 2020.

(Northbound) and $11.32 \%$ at Mbok towards Abakaliki (Southbound) on a daily average. In the several days of the week, the survey was conducted. HGVs have a reasonable share of the traffic components. 
Table 6. Summary of automatic traffic count showing axle load distribution for Abakiliki-Ogoja.

\begin{tabular}{cccccccc}
\hline & $2 \mathrm{aR}$ & $3 \mathrm{a} \mathrm{R}$ & $4 \mathrm{aR}$ & $3 \mathrm{aA}$ & $4 \mathrm{aA}$ & $5 \mathrm{aA}$ & $6 \mathrm{aA}$ \\
\hline $27 / 01 / 19$ & 705 & 26 & 73 & 1 & 64 & 20 & 42 \\
$28 / 01 / 19$ & 634 & 25 & 83 & 0 & 70 & 18 & 40 \\
$29 / 01 / 19$ & 751 & 47 & 41 & 0 & 46 & 12 & 30 \\
$30 / 01 / 19$ & 746 & 57 & 36 & 1 & 39 & 14 & 21 \\
$31 / 01 / 19$ & 723 & 74 & 29 & 1 & 27 & 8 & 18 \\
$01 / 02 / 19$ & 692 & 77 & 40 & 1 & 51 & 12 & 23 \\
$02 / 02 / 19$ & 502 & 67 & 26 & 1 & 25 & 7 & 18 \\
Total k & 1755 & 373 & 328 & 5 & 322 & 91 & 192 \\
\% overloaded & $28 \%$ & $40 \%$ & $35 \%$ & $40 \%$ & $35 \%$ & $33 \%$ & $0 \%$ \\
Number of HGV's overloaded & 491 & 149 & 115 & 2 & 113 & 30 & 0 \\
\hline
\end{tabular}

Note: a-axle, R-Rigid Vehicles, A-Articulated Vehicles. Source: Authors' Computation, 2020.

Table 7. Summary of automatic traffic count showing axle load distribution for Ilorin-Jebba.

\begin{tabular}{cccccccc}
\hline & $2 \mathrm{aR}$ & $3 \mathrm{a} \mathrm{R}$ & $4 \mathrm{aR}$ & $3 \mathrm{aA}$ & $4 \mathrm{aA}$ & $5 \mathrm{aA}$ & $6 \mathrm{aA}$ \\
\hline $15 / 05 / 19$ & 490 & 70 & 118 & 1 & 904 & 290 & 264 \\
$16 / 05 / 19$ & 556 & 73 & 124 & 0 & 953 & 282 & 273 \\
$17 / 05 / 19$ & 527 & 65 & 123 & 2 & 964 & 316 & 306 \\
$18 / 05 / 19$ & 476 & 63 & 116 & 1 & 954 & 295 & 263 \\
$19 / 05 / 19$ & 447 & 49 & 119 & 0 & 1236 & 359 & 339 \\
$20 / 05 / 19$ & 409 & 41 & 96 & 0 & 864 & 238 & 279 \\
$21 / 05 / 19$ & 527 & 64 & 120 & 0 & 990 & 303 & 322 \\
Total k & 3432 & 425 & 816 & 4 & 6865 & 2083 & 2046 \\
\% overloaded & $80 \%$ & $88 \%$ & $75 \%$ & $88 \%$ & $75 \%$ & $64 \%$ & $73 \%$ \\
\hline
\end{tabular}

Note: a-axle, R-Rigid Vehicles, A-Articulated Vehicles. Source: Authors' Computation, 2020.

In Ilorin-Jebba road, $80 \%$ of the 2 -axle trucks are found to be overloaded followed by 3 -axle vehicles, $88 \%$ and 4 -axle vehicles, $75 \%$. Three axles articulated were $88 \%$ overloaded, four axles articulated $75 \%$, and five axles articulated $64 \%$, while 6 -axle articulated were also overloaded at $73 \%$. In all the roads studied, there was a considerable level of overloading on the highway. This validates the implication of overloading on the service life of the road pavement in Nigeria. The pattern is consistent throughout the study. Compared to other countries, the percentage of overloading is exceptionally high. Another study in Poland, the percentage of overloaded vehicles varies from 6 to 16.5 percent, which is quite low when compared to these results [17].

Tables 8-10 indicate the outline of Automatic Traffic Count showing axle 
Table 8. Summary of axle load survey indicating axle load distribution for Lokoja-Abuja.

\begin{tabular}{ccccc}
\hline VT & TNV & NV & N.V. & \% of Overloaded Vehicles \\
\hline $2 \mathrm{~A}$ & 10 & 8 & 2 & $20 \%$ \\
$3 \mathrm{~A}$ & 6 & 3 & 3 & $50 \%$ \\
$4 \mathrm{~A}$ & 74 & 10 & 64 & $86 \%$ \\
$5 \mathrm{~A}$ & 15 & 4 & 11 & $73 \%$ \\
$6 \mathrm{~A}$ & 69 & 4 & 65 & $94 \%$ \\
Total & 174 & 29 & 145 & \\
\hline
\end{tabular}

Note: A-axle, VT-Vehicle Type, TNV-Total Number of Vehicles, NV<-Number of Vehicles within limit, N.V.>-No. of Vehicles above Tolerance limit. Source: Authors' Computation, 2020.

Table 9. Summary of axle load survey indicating axle load distribution for Abakaliki towards Ogoja/Mbock.

\begin{tabular}{ccccc}
\hline VT & TNV & NV & N.V. & \% of Overloaded Vehicles \\
\hline 2A & 39 & 28 & 11 & $28 \%$ \\
$3 \mathrm{~A}$ & 10 & 6 & 4 & $40 \%$ \\
$4 \mathrm{~A}$ & 31 & 20 & 11 & $35 \%$ \\
$5 \mathrm{~A}$ & 9 & 6 & 3 & $33 \%$ \\
$6 \mathrm{~A}$ & 8 & 8 & 0 & $0 \%$ \\
Total & 97 & 68 & 29 & \\
\hline
\end{tabular}

Note: A-axle, VT-Vehicle Type, TNV-Total Number of Vehicles, NV<-Number of Vehicles within limit, N.V.>-No. of Vehicles above Tolerance limit. Source: Authors' Computation, 2020.

Table 10. Summary of axle load survey indicating axle load distribution for Ilorin-Jebba.

\begin{tabular}{ccccc}
\hline VT & TNV & NV< & N.V. & \% of Overloaded Vehicles \\
\hline 2A & 15 & 3 & 12 & $80 \%$ \\
$3 \mathrm{~A}$ & 8 & 1 & 7 & $88 \%$ \\
$4 \mathrm{~A}$ & 80 & 20 & 60 & $75 \%$ \\
$5 \mathrm{~A}$ & 22 & 8 & 14 & $64 \%$ \\
$6 \mathrm{~A}$ & 15 & 4 & 11 & $73 \%$ \\
Total & 140 & 36 & 104 & \\
\hline
\end{tabular}

Note: A-axle, VT-Vehicle Type, TNV-Total Number of Vehicles, NV<-Number of Vehicles within limit, N.V.>-No. of Vehicles above Tolerance limit. Source: Authors' Computation, 2020.

load distribution for Lokoja-Abuja, Abakiliki-Ogoja and Ilorin-Jebba roads. We can deduce the number of G.V.W. violations (based on maximum permissible G.V.W. of ECOWAS standard). The rate of G.V.W. violation is found to range between $20 \%$ and $94 \%$ of the axle load distribution. Heavy vehicles in Nigeria is conventionally classified by the number of axles, namely from the 2-axle up to the 6 -axle trucks. In Lokoja-Abuja road, $20 \%$ of the 2 -axle trucks are found to be overloaded followed by 3 -axle vehicles, $50 \%$ and 4 -axle vehicles, $86 \%$. Three axles articulated were $50 \%$ overloaded, four axles articulated $86 \%$, five axles ar- 
ticulated $73 \%$, while 6 -axle articulated were predominantly overloaded at $94 \%$. In Abakiliki-Ogoja road, $28 \%$ of the 2 -axle trucks are found to be overloaded followed by 3 -axle vehicles, $40 \%$ and 4 -axle vehicles, $35 \%$. Three axles articulated were $40 \%$ overloaded, four axles articulated $35 \%$, and five axles articulated $33 \%$, while 6-axle articulated were not overloaded at $0 \%$. They are not overloaded at $0 \%$.

It can be seen from Tables 8-10 that of 174 vehicles surveyed at Lokoja-Abuja; approximately, $83.3 \%$ (145 numbers) of the trucks were found to be overloaded. Six axle trucks was observed to be more overloaded, closely is followed by four-axle and five-axle vehicles. Also, all the multi-axle trucks passing through this section are found to be overloaded. At Abakaliki towards Ogoja/Mbock, more than $29 \%$ (29 numbers) of the trucks were found to be overloaded. Three axle trucks contribute a considerable amount of overloaded truck which is followed by four-axle and five-axle vehicles. Also, all the multi-axle trucks passing through this section were not overloaded at all. Also at Ilorin-Jebba, more than $74 \%$ (104 numbers) of the trucks were found to be overloaded. Three axle trucks contribute a considerable amount of overloaded truck which is followed by two-axle and four-axle vehicles. Also, all the multi-axle trucks passing through this section are found to be overloaded at $73 \%$.

\subsection{Analysis of the Serviceability of Pavement Segments}

In addition to modelling the effects of axle passes, it is necessary to measure the serviceability of pavement segments for the estimation of pavement damage. The application of pavement characteristics in pavement deterioration models played another crucial role in this pavement damage cost study. Based on individual observations, the researchers developed study instrument to assess the present serviceability rating (P.S.R. or p) as the judgment of road users and other transport practitioners were sought as to the current ability of pavement to serve the traffic it is meant to serve. The P.S.R. scores were generated by respondents who drove along the sections of the road network being studied and rated their ride quantitatively. This subjective scale ranges from 5 (excellent) to 0 (Very Poor). As Table 11 depicts, the smoothness of the ride, as well as the extent of rutting and other, distresses. Modelling a decline in P.S.R. is, to a certain extent, modelling the occurrence of individual distresses as well.

Using a weighted average for the one hundred responses from the road users, the present serviceability ratings for the various road segment under study is shown in Table 11.

\subsubsection{Analysis of Present Serviceability Rating of Lokoja-Abuja Road} The present serviceability rating for this road is estimated at 3.45. The road is relatively in good condition. By implication, the Lokoja-Abuja road, although not quite as smooth as when it was initially commissioned in 2014, give a first-class ride and exhibits some signs of surface deterioration. The road is beginning to show evidence of rutting, alligator cracks, and peeling. Table 12 gives a concise picture of evidence of deterioration on the road segment. 
Table 11. Present serviceability ratings.

\begin{tabular}{ccccccc}
\hline Road & Excellent & Good & Fair & Poor & Very Poor & P.S.R. \\
\hline Lokoja-Abuja Road & 0 & 61 & 24 & 14 & 1 & 3.45 \\
Ilorin-Jebba Road & 51 & 39 & 10 & 0 & 0 & 4.41 \\
Abakiliki-Ogoja Road & 2 & 44 & 41 & 13 & 0 & 3.35 \\
\hline
\end{tabular}

Excellent $=5$, Good $=4$, Fair $=3$, Poor $=2$ and Very Poor $=1$. Source: Authors' Computation, 2020 .

Table 12. Evidence of road failure along Lokoja-Abuja road.

\begin{tabular}{|c|c|c|c|c|}
\hline$S / N$ & Type of failure & Location & Photograph & Remark \\
\hline 1. & $\begin{array}{l}\text { Alligator cracks, } \\
\text { Peeling. }\end{array}$ & KM18+800 & & $\begin{array}{c}\text { Failure on the centre of } \\
\text { R.H.S. carriageway }\end{array}$ \\
\hline 2. & Pothole & KM19+050 & & $\begin{array}{c}\text { Failure on the centre of } \\
\text { R.H.S. carriageway }\end{array}$ \\
\hline 3. & $\begin{array}{l}\text { Alligator cracks, } \\
\text { Peeling. }\end{array}$ & KM19+800 & & $\begin{array}{c}\text { Failure on the centre of } \\
\text { R.H.S. carriageway }\end{array}$ \\
\hline 4. & Rut & KM25+750 & & $\begin{array}{l}\text { Repair of Failure on } \\
\text { R.H.S. carriageway }\end{array}$ \\
\hline 5. & $\begin{array}{l}\text { Alligator cracks, } \\
\text { Pothole }\end{array}$ & $\mathrm{KM} 27+300$ & & $\begin{array}{l}\text { Repair of Failure on } \\
\text { R.H.S. carriageway }\end{array}$ \\
\hline 6. & Rut & $\mathrm{KM} 28+250$ & & $\begin{array}{l}\text { Repair of Failure on } \\
\text { R.H.S. carriageway }\end{array}$ \\
\hline
\end{tabular}

Source: Authors' Compilation (2019).

\subsubsection{Analysis of Present Serviceability Rating of Ilorin-Jebba Road}

The present serviceability rating for this road is estimated at 4.41 . This falls within the category of excellent rating. Along Ilorin-Jebba Road new (or nearly new) superior pavements are smooth enough and distress free (sufficiently free of cracks and patches). This road is relatively new, being constructed or resurfaced in. Table 13 gives a concise picture of evidence of the present state of the road segment.

\subsubsection{Analysis of Present Serviceability Rating of Abakiliki-Ogoja Road}

The present serviceability rating for this road is estimated at 3.35. Similar to that of Lokoja-Abuja road, the road is relatively in good condition. Pavements are not quite as smooth as those of Ilorin-Jebba, but it gives a first-class ride and exhibits some few signs of massive deterioration at some few locations. The flexible pavements are beginning to show evidence of pothole, alligator cracks, depression and upheaval. Table 14 gives a concise picture of evidence of the present state of the road segment. 
Table 13. Evidence of road failure along Ilorin-Jebba Road.

\begin{tabular}{|c|c|c|c|c|}
\hline $\mathrm{S} / \mathrm{N}$ & Type of failure & Location & Photograph & Remark \\
\hline 1. & Raveling & KM39+450 & & $\begin{array}{l}\text { Failure on the } \\
\text { right-hand side }\end{array}$ \\
\hline 2. & Pothole & KM76+750 & & $\begin{array}{l}\text { Failure on the } \\
\text { right-hand side }\end{array}$ \\
\hline 3. & Peeling & KM77+600 & & $\begin{array}{c}\text { Failure on the centre of } \\
\text { the carriageway }\end{array}$ \\
\hline 4. & Pothole & KM79+500 & & $\begin{array}{l}\text { Failure on the } \\
\text { right-hand side }\end{array}$ \\
\hline 5. & $\begin{array}{c}\text { Alligator cracks, } \\
\text { Pothole }\end{array}$ & KM76+080 & & $\begin{array}{l}\text { Failure on the } \\
\text { right-hand side with } \\
\text { the patched pothole }\end{array}$ \\
\hline 6. & Rut & KM76+300 & & Repair of Failure \\
\hline
\end{tabular}

Source: Authors' Compilation (2019).

Table 14. Evidence of road failure along Abakiliki-Ogoja Road.

\begin{tabular}{|c|c|c|c|c|}
\hline $\mathrm{S} / \mathrm{N}$ & Type of failure & Location & Photograph & Remark \\
\hline 1. & Potholes, Alligator cracks & KM8+600 & & $\begin{array}{l}\text { Failure on both } \\
\text { lanes. }\end{array}$ \\
\hline 2. & $\begin{array}{c}\text { Pothole, block cracks, } \\
\text { depression. }\end{array}$ & KM10+900 & & $\begin{array}{l}\text { Failure on both } \\
\text { lanes. }\end{array}$ \\
\hline 3. & $\begin{array}{c}\text { Pothole, Alligator cracks, } \\
\text { depression, upheaval. }\end{array}$ & $\mathrm{KM} 12+500$ & & $\begin{array}{l}\text { Failure on both } \\
\text { lanes. }\end{array}$ \\
\hline 4. & Alligator cracks, depression. & $\mathrm{KM} 13+700$ & & $\begin{array}{l}\text { Failure on the left } \\
\text { lane. }\end{array}$ \\
\hline 5. & Alligator cracks, pothole & $\mathrm{KM} 15+000$ & & Failure on both \\
\hline
\end{tabular}




\section{Continued}

6.

Potholes, Depression, Alligator cracks, upheaval.

KM15+100

7. Potholes, Alligator cracks

KM19+400

8. Pothole, Alligator cracks.

KM20+200

9. Potholes, Alligator cracks.

$\mathrm{KM} 22+600$

10.

Pothole, Alligator cracks.

$\mathrm{KM} 22+700$

11.

Pothole, Alligator cracks, depression.

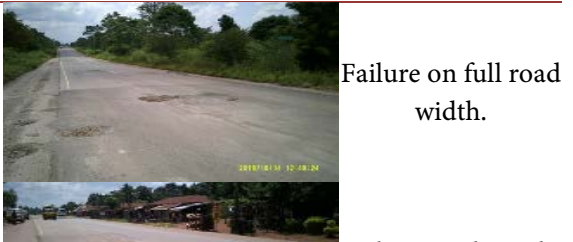

Failure on the right lane.

Failure on the right lane.

Failure on both lanes.

Failure on both lanes.

$\mathrm{KM} 22+750$

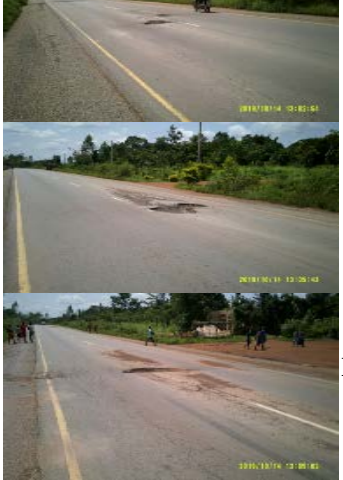

Failure on full road width.

Source: Authors' Compilation (2019).

\subsection{Incremental Load Damage Effects of Overweight Trucks on Federal Highway Pavement Structures}

Traffic loading, for example, is such a heterogeneous mixture of many factors, varying from road to road, over time with traffic growth and changes in technology. We are compelled to satisfy two extreme demands, namely: to define a practical and relevant summary statistic representing the joint effects of traffic loading for use in design; and to determine the relative damaging effects arising from individual axle loadings, axle configurations, tire sizes, types and pressures, and from the dynamic effects associated with vehicle speed and individual suspension-types, in such a way that the impact on the marginal costs of road damage and the optimum vehicle design and loading regulations can be evaluated for each factor.

The standard approach now for road pavements is to reduce mixed traffic loadings to the single unit of equivalent standard axle loadings (ESAL), which is the number of passages of a standard axle load that cause the same amount of damage as the mixed traffic. The attraction of a normalized damage function is that it expresses the fraction of terminal damages. It so relates readily to an interpretation of the "consumed life" or "remaining life" of a pavement. In this study, indices of measuring the deterioration effects of the high grade vehicles (HGVs) are shown in Table 15. 
Table 15. Highway deterioration indices.

\begin{tabular}{cccccccc}
\hline Road & ADT & PSR & $\boldsymbol{P}_{E}$ & $\boldsymbol{\delta}$ & $\boldsymbol{\beta}$ & $\boldsymbol{\beta}_{18}$ & $\boldsymbol{g}$ \\
\hline Lokoja-Abuja Road & 2852 & 3.45 & 3.93 & 0.027 & 0.44 & 0.46 & 0.30 \\
Ilorin-Jebba Road & 2248 & 4.41 & 4.38 & 0.027 & 0.49 & 0.46 & 0.35 \\
Abakiliki-Ogoja Road & 662 & 3.35 & 3.63 & 0.027 & 0.44 & 0.46 & 0.43 \\
\hline
\end{tabular}

Source: Authors' Computation, 2020.

The damage index g defined the fractional change of serviceability index are $0.30,0.35$ and 0.43 for Lokoja-Abuja Road, Ilorin-Jebba Road and Abakiliki-Ogoja Road respectively. This ratio explains the loss in serviceability at time $t$ to the potential loss taken at a point where P.T. $=3.0$. The trend of the damage function, therefore, expresses the performance of the pavement about two standards, the quality of original construction or initial condition $\left(P_{i}\right)$ and the "terminal" level of distress at which maintenance or rehabilitation is deemed necessary $\left(P_{T}\right)$. The base of the function, therefore, changes as one or other of these two standards alters. The predictive models of AASHTO all take this form of dimensionless damage functions. Hence, the damaging effects of the HGV are more severe at Lokoja-Abuja Road (with $g=0.30$ ), followed by Ilorin-Jebba Road (with $g=0.35$ ) and Abakiliki-Ogoja Road (with $g=0.43$ ). The more substantial overload of $94 \%$ of the 6 -axle vehicles from cement carrying articulated vehicles plying at the Lokoja-Abuja road could explain this intense damaging effect on the road pavement.

While time (and thus age) is a universal dimension, the environmental factors which influence non-traffic-associated damage are not captured. Although the effects of individual factors such as rainfall, temperature, oxidation, materials and freezing can be identified conceptually, and to a minimal extent theoretically. The overall impact is so complicated by the interactions and combined effects that empirical distinctions are impracticable and regional averaging is inevitable. In the present study, the non-traffic-associated effects have been quantified in coefficients $\left(P_{E}\right)$, and these are being related to environmental factors through comparative studies with independent databases from other climates. The approach of environmental classification appears to be the most practical since it captures the significant effects and makes empirical validation feasible. In Table 15, the P.S.R. due to the environmental impact $\left(P_{E}\right)$ for Lokoja-Abuja Road, Ilorin-Jebba Road and Abakiliki-Ogoja Road are 3.93, 4.38 and 3.63, respectively. This is closely related to the P.S.R. estimated by traffic users and operators survey of 3.45, 4.41 and 3.35 for Lokoja-Abuja Road, Ilorin-Jebba Road and Abakiliki-Ogoja Road. This shows that the present serviceability ratings of Nigerian road are more traffic-loading determined than from environmental concerns.

\section{Conclusions}

The present serviceability rating for Lokoja-Abuja Road is estimated at 3.45. The road is relatively in good condition. By implication, the Lokoja-Abuja Road, al- 
though not quite as smooth as when it was initially commissioned in 2014 , gives a first-class ride. It exhibits few, if any, visible signs of surface deterioration. The road is beginning to show evidence of rutting, alligator cracks, and peeling. The present serviceability rating for Ilorin-Jebba road is estimated at 4.41. This falls within the category of excellent rating. Along Ilorin-Jebba Road, new (or nearly new) superior pavements are smooth enough and distress free (sufficiently free of cracks and patches). This road is relatively new, being constructed in 2019. The present serviceability rating Abakiliki-Ogoja Road is estimated at 3.35. Similar to that of Lokoja-Abuja road, the road is relatively in good condition.

The pavement surface is not quite as smooth as those of Ilorin-Jebba, but it gives a first-class ride and exhibits few signs of surface deterioration. This flexible pavement is beginning to show evidence of pothole, alligator cracks, depression and wheel rutting. Hence, the damaging effects of the HGV are more severe at Lokoja-Abuja Road (with $g=0.30$ ), followed by Ilorin-Jebba Road (with $g=$ 0.35) and more in Abakiliki-Ogoja Road (with $g=0.43$ ). The more substantial overload of $94 \%$ of the 6 -axle vehicles mostly carrying cement plying at the Lokoja-Abuja road could explain this intense damaging effect on the road pavement. The P.S.R. due to the environmental impact $\left(P_{E}\right)$ for Lokoja-Abuja Road, Ilorin-Jebba Road and Abakiliki-Ogoja Road are 3.93, 4.38 and 3.63 respectively. This is closely related to the P.S.R. estimated by traffic users and operators survey of 3.45, 4.41 and 3.35 for Lokoja-Abuja Road, Ilorin-Jebba Road and Abakiliki-Ogoja Road. This shows that the present serviceability ratings of Nigerian road are more traffic-loading determined than from environmental concerns.

In this paper, we recommend further systematic pavement damage estimation procedure that will synthesize several existing methodologies including Highway Economic Requirements System (HERS) and American Association of State Highway and Transportation Officials (AASHTO) methods. The procedure will provide a practical approach to estimate pavement damage costs attributed to truck traffic on specific pavement segments. Using this approach, general pavement damage costs associated with high grade vehicle could also be estimated if the truck traffic volume and predominant truck types were known. The methodology will enable the government to proactively maintain its critical transportation infrastructure in a state of good repair without compromising traveler safety and costs. It helps to develop win-win strategies for both road users and road managers, and it helps to maximize economic returns on Nigeria' Road Transportation System.

\section{Conflicts of Interest}

The authors declare no conflicts of interest regarding the publication of this paper.

\section{References}

[1] Bushman, R., Berthelot, C. and Taylor, B. (2003) Commercial Vehicle Loading in an Urban Environment. The Emerging Technologies in Traffic Operations Session of the 2003 Annual Conference of the Transportation Association of Canada St. 
John's, Newfoundland and Labrador, Canada, from September 21 to 24. http://conf.tac-atc.ca/english/resourcecentre/readingroom/conference/conf2003/pdf s/bushman1.pdf

[2] Santero, N.J., Nokes, W. and Harvey, J.T. (2005) Virtual Weigh Stations: The Business Case. Institute of Transportation Studies, University of California, Davis, Research Report UCPRC-TM-2005-03.

[3] Transportation Research Board (1990) Truck Weight Limits: Issues and Options-Special Report 225.

[4] Straus, S.H. and Semmens, J. (2006) Estimating the Cost of Overweight Vehicle Travel on Arizona Highways. Arizona Department of Transportation, Arizona, Final Report 528.

[5] Titus, M.J. (1996) Benefits of Electronic Clearance for Enforcement of Motor Carrier Regulations. Transportation Research Record, 1522, 64-68. https://doi.org/10.1177/0361198196152200108

[6] Mulyono, A.T., Parikesit, D., Antameng, M. and Rahim, R. (2010) Analysis of Loss Cost of Road Pavement Distress due to Overloading Freight Transportation. Journal of the Eastern Asia Society for Transportation Studies, 8, 706-721.

[7] World Bank and FMT (2008) Axle Load Study and Review and Update of design Standards for Federal Roads, Nigeria. Federal Government of the Republic of Nigeria Report on the Axle Load Study by SSI Engineers and Environmental Consultants (Pty) Ltd. South Africa T01.IBU.000064, Submitted to Federal Ministry of Transportation (Works).

[8] Podborochynski, D., Berthelot, C., Anthony, A., Marjerison, B., Litzenberger, R. and Kealy, T. (2011) Quantifying Incremental Pavement Damage Caused by Overweight Trucks. The Effects of Increased Loading on Pavement Session of the 2011 Annual Conference of the Transportation Association of Canada, Edmonton, Alberta, Canada, from September 11-14.

http://conf.tac-atc.ca/english/annualconference/tac2011/docs/p1/podborochynski.p df

[9] ARRB Transport Research (1997) Assessment of Truck/Trailer Dynamics. Technical Working Paper No. 31, Contract Report, National Road Transport Commission.

[10] Saifizul, A.A., Yamanaka, H. and Karim, M.R. (2011) The Empirical Analysis of Gross Vehicle Weight and Free-Flow Speed and Consideration on Its Relation with the Differential Speed Limit. Accident Analysis and Prevention, 43, 1068-1073. https://doi.org/10.1016/j.aap.2010.12.013

[11] Saifizul, A.A., Yamanaka, H., Karim, M.R. and Okushima, M. (2011) The Empirical Analysis of the Effect of Gross Vehicle Weight and Vehicle Size on Speed in the Car Following Situation. Proceedings of the Eastern Asia Society for Transportation Studies, 8, 305-317.

[12] Jacob, B. and La Beaumelle, V.F. (2010) Improving Truck Safety: Potential of Weigh-in-Motion Technology. IATSS Research, 34, 9-15.

https://doi.org/10.1016/j.iatssr.2010.06.003

[13] Balducci, P. and Stowers, J. (2008) State Highway Cost Allocation Studies, a Synthesis of Highway Practices. National Cooperative Highway Research Program Synthesis, Washington DC, Report 378.

[14] Oyekanmi, O.J., Ibe, C.C., Ebiringa, O.T. and Ejem, E.A. (2020) Analysis of the Extent of Overloading on the Nigerian Highways. International Journal of Transportation Engineering and Technology, 6, 22-29.

https://doi.org/10.11648/j.ijtet.20200601.14 
[15] Oyekanmi, O.J., Ibe, C.C., Ebiringa, O.T. and Ejem, E.A. (2020b) Estimation of the Impact of the Overloaded Truck on the Service Life of Pavement Structures in Nigeria. International Journal of Traffic and Transportation Engineering, 9, 41-47.

[16] Bai, Y., Schrock, S.D., Mulinazzi, T.E., Hou, W., Liu, C.X. and Firman, U. (2010) Estimating Highway Pavement Damage Costs Attributed to Truck Traffic. Final Reports \& Technical Briefs from Mid-America Transportation Center. http://digitalcommons.unl.edu/matcreports/55

[17] Rys, D., Judycki, J. and Jaskula, P. (2016) Analysis of the Effect of Overloaded Vehicles on Fatigue Life of Flexible Pavements Based on Weigh-in-Motion (WIM) Data. International Journal of Pavement Engineering, 17, 716-726.

https://doi.org/10.1080/10298436.2015.1019493 